\title{
PARTNEREK A TANÁRKÉPZÉSBEN
}

\author{
DÖMSÖDY ANDREA* - SZARKA EMESE** \\ * az Oktatáskutató és Fejlesztő Intézet - Országos Pedagógiai Könyvtár és Múzeum \\ iskolai könyvtári szakreferense \\ domsody.andrea@opkm.hu \\ ** az Eötvös Loránd Tudományegyetem Pedagógiai és Pszichológiai Kar \\ Neveléstudományi Doktori Iskolájának doktorandusz hallgatója \\ 2ianus2@gmail.com
}

Az Oktatási és Kulturális Minisztérium (OKM) és az Oktatáskutató és Fejlesztő Intézet (OFI) munkacsoportja „Javaslatok a tanárképzés utolsó, gyakorlati félévével kapcsolatos szakmai és gyakorlati kérdésekröl" címmel elkészített munkaanyag bemutatására egynapos konferenciát szervezett a Duna Palotába. A részletes és a résztvevők által általában előremutatónak, koncepciójában támogathatónak tartott 104 oldalas munkaanyagot minden elözetesen a konferenciára regisztráló e-mailben megkapta. Így annak részletes bemutatása helyett az OKM szempontjait és négy kiemelt szakmai szervezet véleményét ismerhették meg a résztvevők a délutáni szekciómunkák elött.

\section{Összefüggő szakmai gyakorlat a tanárképzés ötödik félévében}

A munkaanyag és így a konferencia sem a teljes tanári mesterképzéssel (MA), és nem is annak gyakorlataival, hanem kizárólag az új, öt féléves tanárképzés ötödik félévével foglalkozott. Az új képzési struktúrában az ötödik félév a pedagógiaipszichológiai és szakmódszertani kurzusok és a tanítási gyakorlat elvégzése után az önálló, a képzés és a pedagógusi munka között átmenetet képező gyakorlat elvégzését szolgálja.

Manherz Károly felsőoktatási és tudományos szakállamtitkár (OKM) megnyitó előadásában röviden bemutatta az összefüggő tanárképzési szakmai gyakorlat oktatáspolitikai kapcsolódásait. Magyarországon a 11/1997-es Kormányrendelet óta nem volt ilyen nagymértékü átalakítás a tanárképzésben. A Bologna-folyamat gyökeresen alakítja át a rendszert. Az átalakítás eredményeként megszületett ötödik félév nem gyökerek nélkül való. Ilyen jellegü gyakorlati (fél)évre minta a német és osztrák modell, és jó tapasztalatokat mutató magyar példa az 1990-es évek elején müködött hároméves nyelvtanárképzés. Mindemellett jelentős erőssége, az európai elvárásoknak is a megfelelö együttmüködésre alapuló tanárképzési szerkezet. Ez nemcsak 
a gyakorlóiskolákat, hanem egy partneriskolai hálózatot von be a képzésbe, nem elfelejtkezve az iskolafenntartó szervezetek bevonásáról sem.

Ezt követően hét előadó mutatta be álláspontját és észrevételeit a munkaanyaggal kapcsolatban. Elsőként Csillag Márta az Oktatási és Kulturális Minisztérium föosztályvezető asszonya világított rá a közoktatás tanárképzéssel kapcsolatos elvárásaira. Előadásában kiemelte, hogy a felsőoktatás és a közoktatás partnerségének egyik alappillére, hogy a képzés a közoktatás elvárásait figyelembe véve müködik. Szerinte a közoktatásnak tudatosabban kell a jövőben vállalnia megrendelö szerepét. Ezzel összhangban üdvözölte az új képzés gyakorlati ismereteket előtérbe helyező és gyakorlatközelibb koncepcióját. Majd sorolta mindazokat a közoktatási kihívásokat (eredményességi problémák kezelése; általános készségek hiánya, „,szakiskolai gödör"; társadalmi egyenlőtlenségek; a munkaerö-piacon való elhelyezkedés nehézsége), melyekkel kapcsolatban elvárásokat, reményeket támaszt a közoktatás. Reményei szerint a Bologna-folyamat tudatosabb pályaválasztásra ösztönöz, megerősíti a gyakorlatot, felértékeli a pedagogikumot és a módszertant, és rugalmasabb foglalkoztatást tesz majd lehetővé. Fontosnak tartja, hogy a közoktatási intézmények a tanárképzés felelős résztvevőjévé válnak ebben a szerkezetben. Így elvárásként fogalmazható meg a gyakorló és partneriskolák egyértelmü elválasztása, az iskola teljes világának megismertetése, így „,valóságos” közoktatási intézmények bevonása, a müködési szabályok, feladatok egyértelmü meghatározása és ezzel párhuzamosan a finanszírozási kérdések megoldása. A partneriskolai gyakorlatvezető mentorságot pedig a pálya egyfajta szakmai előmeneteli, elismerési lehetőségeként értelmezte, mely a pedagóguspolitika szerves része lehet.

Két alapvető kötelezettségre hívta még fel Csillag Márta a figyelmet. Egyrészt a gyakornoki rendszer kötelezettségeinek megfogalmazására (idő, mentor stb. meghatározása), másrészt a keretszerződés kötésre. Csillag Márta a fenntartóval tartja fontosnak ezt a szerződést megkötni, arra hivatkozva, hogy a fenntartó felel a feltételek biztosításáért. Ez utóbbi véleménnyel kapcsolatban megoszlottak a nézetek, ki felértékelte a fenntartó szerepét, ki pedig azt vallotta, hogy a szerződéseket sokkal inkább az intézményvezetővel vagy a gyakorlatvezető tanárokkal érdemes megkötni. Ez ügyben végleges döntés még nem született.

Iker János (föiskolai docens, igazgató, Nyugat-magyarországi Egyetem, Regionális Szolgáltató és Kutató Központ, Szombathely) a Javaslatot kidolgozó munkabizottság tagjaként a tervezetet és a véleményeket felvezetendő elmondta, hogy ez az anyag javaslat egy jogszabályokhoz kapcsolódó elemzéshez. Vagyis nem egy újabb jogszabály előkészítéséről, hanem az új képzési forma jogszabályi környezetbe ágyazott bemutatását, a problémafelvetést és az ajánlásokat szolgálja. Álláspontja szerint egy módszertani paradigmaváltásra van szüksége a szakmának. Hangsúlyozta a gyakorlatvezetők fontosságát és elismerését. Váljon minden gyakorlati feltétel és szervezés tanterem közelivé, gyerek közelivé. 


\section{Kiemelt szervezetek véleménye a Javaslatról}

A bevezető előadásokat követően öt felkért hozzászólónak volt lehetősége plenárisan véleményezni a Javaslatot. A hozzászólók abban egyetértettek, hogy a képzési koncepció elöremutató, a munkaanyag alapjában véve alapos, de nem támogatnák az ilyen részletes szabályozást. Visszatérő problémaként merült fel a finanszírozás nem elhanyagolható problémája.

A felkért véleményezők sorát a Magyar Rektori Konferencia Pedagógusképzési Bizottsága kezdte, mely szervezet véleményét 13 véleményt mondó anyagát feldolgozva Hoffmann Rózsa egyetemi docens (Pázmány Péter Katolikus Egyetem) mutatta be. Mivel az új rendszerü tanárképzés már több intézményben folyik, és további intézmények már rendelkeznek erre nézve akkreditációval, továbbá az egyetemi autonómia megőrzése érdekében is fontos, hogy a képzés ezen szakasza ne legyen túlszabályozott. Konkrétabb javaslatai közt elsőként szerepelt a résztvevők felelősségének, kötelességének, feladatának, hatáskörének pontosabb tisztázása, melyen belül a gyakorló hely kiválasztásának jogát meg kell hagyni a képzőintézménynek. Szintén a felelösség témájához kapcsolható a tanárjelölt nevelötestületben elfoglalt helye, hogy munkájára legyen felelősséggel, de minderről a szülöket egyértelmüen tájékoztassák. Továbbá nem javasolják az összefüggő gyakorlat több iskola közti megbontását. Hoffmann Rózsa beszámolója kitért az anyagi juttatások kérdésére is. Három hely támogatását tartja elengedhetetlennek: a hallgatói juttatást (hiszen a hallgató munkát végez), a gyakorlóhely félévenkénti normatív juttatását és a mentorok pótlékát. A mentorképzés képesítési követelményeit le kell fektetni. Javaslata szerint szakirányú szakvizsgára van szükség (2015-ig minimum 60 órás képzés keretében). A gyakorlóhelyen szükséges, hogy szakképzett mentor is alkalmazásban legyen, és az is fontos lenne, hogy magának az intézmény vezetőjének is legyen szakvizsgája. Amennyiben a mentor tanár nem olyan szakos, mint a hallgató, az esetben el kell különíteni egymástól a szakos és a nem szakos tanítást. Szakos tanításnál plusz egy szaktanárt kell kijelölni, minden egyéb esetben elég egy mentortanár a jelölt mellé. A képző hely alkalmasságát az Akkreditációs Bizottság értékelje. A hallgatók jogait és lehetőségeit, hogy mit szabad és mit nem megtenniük a gyakorlóhelyen (pl. videofelvételt készíteni), külön szabályzatba vagy a keretszerződésbe kell foglalni,

A Nemzeti Bologna Bizottság Pedagógusképzési Albizottságának véleményét elnöke, Hunyady György egyetemi tanár (Eötvös Loránd Tudományegyetem) mutatta be. Javasolta, hogy bár ez a Javaslat csak az ötödik féléves gyakorlattal foglalkozik, kerüljön egyértelmübb bemutatásra a tanárképzés háromféle gyakorlatának funkciója, és ehhez kapcsolva a szakterület és a pedagógia-pszichológia viszonya. A felsőoktatási autonómiához kapcsolódva a partneriskolák (gyakorló helyek) regionális, országos szervezését nem látja szükségesnek. Az Albizottság szintén az egy helyen eltöltött gyakorlatot támogatja, hiszen így kaphat a tanárjelölt mélyebb, 
alaposabb képet az iskola egészéről. Továbbá szintén felvetette a tanárjelölt hallgató iskolai jogállásának problémáját, hiszen ebben a félévben önálló munka a feladata.

Tasnádi Péter egyetemi tanár (Eötvös Loránd Tudományegyetem Tanárképzési és Tanártovábbképzési Tanácsának elnökhelyettese) a természettudományi képzés szemszögéből vizsgálta meg a munkaanyagot. Álláspontja szerint a gyakorlatot a képzöhelyen nem blokkszemináriummal kellene követni, hanem heti rendszerességü pedagógiai-pszichológiai és szakmódszertani szemináriummal kellene támogatni. Felvetette, hogy a gyakorlatvezetö mentortanárt nem honoráriummal, hanem óraszámkedvezménnyel kellene ,fizetni”.

Falus Iván egyetemi tanár a Tanárképzök Szövetségének elnöke (Eszterházy Károly Föiskola) húsz pontos írásban is kiosztott javaslataik közül kiemelte, hogy ennek a félévnek a képzés és a gyakorlat közötti átmenet biztosításában látják jelentőségét, de felvetette a félévkor végzők további foglalkoztatásának kérdését. Ehhez kapcsolódóan hangsúlyozta, hogy nagyon fontos a teljes képzés, pályakezdés és pálya egységben kezelése. Továbbá javasolta, hogy a hallgatónak a partneriskolában mindkét szakjához kapcsolódóan legyen felelős segítője. A Tanárképzők Szövetsége fontosnak tartja, hogy a diplomaszerzés utáni féléves intenzív szakasz tartalmi és szervezési, munkajogi kérdései egyértelműen kerüljenek megfogalmazásra, azaz világosan legyenek leírva a közoktatás és felsőoktatás, a fogadó iskola és a gyakornok teendői, jogai és kötelezettségei. A 15/2006-os rendelet kilenc tanárképzési kompetenciát sorol fel. Ezek azonban túl általánosak, a pedagógus előmenetelének megállapítására nem alkalmasak. Éppen ezért konkrét sztenderdek felállítására van szükség, például abban is, hogy kit lehet alkalmazni, pedagógus pályára kiengedni. A mentorok megválasztásánál, a mentori státusz rangjának megteremtésénél és odaítélésénél szintén meghatározott elvárásokra van szükség. Határozottabban kellene megfogalmazni, hogy az OKM-nek milyen feladatai vannak a mentorképzés inspirálása és a mentorok mind erkölcsi, mind pedig anyagi megbecsülésének megteremtése terén. A mentorság felfogható lehetne úgy is, mint a pedagóguspálya csúcsa. A Tanárképzők Szövetsége nem tartja indokoltnak még egy személy (,„pedagógiai szakértő" bevonását a mentor és a gyakorlatvezetô oktató mellett.

A plenáris hozzászólások sorát Országos Köznevelési Tanács nevében Vass Vilmos egyetemi docens (Pannon Egyetem, Veszprém) zárta. A Tanács véleménye egybecseng abban a tekintetben a többi hozzászólással, hogy világossá kell tenni, rendeleti úton szabályozni, hogy mit kell intézményi belső szabályozással és mit a köz- és felsőoktatási intézmények közötti megállapodások révén megoldani. Csatlakozott az egy partnerintézményben eltöltendő gyakorlatot támogatók sorába, és szintén nem látja szükségességét a partneriskolák központi nyilvántartásának. Bürokratikusnak ítélte a Javaslat hallgatói értékelésre vonatkozó részét. Míg fontosnak ítélte az iskolai komplex gyakorlatot, rámutatott a munkaanyag azon hiányosságára, hogy sok gyakorlati iskolai terület (pl.: osztályfönöki munka, tehetséggondozás, hátrányos helyzet) nem kap helyet benne. Ennek megfelelően pedig rámutatott, hogy 
a tanárjelölt felkészítésében az egész intézménynek részt kell vennie. Végezetül pedig javasolta, hogy az ötödik féléves gyakorlatnak legyen monitorozása.

\section{A résztvevők hozzászólásai}

A program az ebéd után három szekcióban folytatódott, ahol különböző szempontok mentén volt lehetősége a konferencián résztvevőknek is hozzászólni a munkaanyaghoz. Majd a szekcióelnökök plenáris összefoglalója következett.

Halász Gábor egyetemi tanár (Eötvös Loránd Tudományegyetem) A képzőintézmények, valamint a képzök kapcsolatrendszere c. szekció elnöke hét problématerületben foglalta össze a szekció munkáját: 1 . A partnerek definiálása (mely szervezeti egységek) 2. Fenntartó bevonása nélkül nagy a kockázat 3. A tanárképzés eltérő perspektívái miatt nem homogén terület (szakmai, gyógypedagógiai tanárképzés, nem közoktatási intézmények) 4. Időtényező (még folyik a 2005-ös felsőoktatási törvény végrehajtása is.) 5. A tanárképzésnek is tanulnia kell (hazai és külföldi gyakorlatokból) 6. A hallgató iskolát vagy mentort választ? (pl.: müvésztanárképzésben) 7. Mit lehet fél év alatt tenni? Reálisabban kell látni a lehetőségeket. Mindezeken kívül több ponton is felmerült a finanszírozás kérdése.

A képzés tartalma c. szekció vezetője, Vágó Irén tudományos főmunkatárs (Oktatáskutató és Fejlesztő Intézet) hangsúlyozta, hogy ez az anyag javaslat, nem szabályozás, senki autonómiáját nem korlátozza. A felmerülő témákat hat pontban foglalta össze: 1. A képzést a lehető legrugalmasabbá kell tenni. Valóban lehetővé kell tennie az egyéni képzési utakat és az egyéni hallgatói fejlesztést. 2. Bár a többség az egy intézményben eltöltött gyakorlatot támogatta, de a kompetenciák, lehetőségek miatt nem zárnák ki a több helyszín lehetőségét sem. 3. Foglalkozni kell a speciális szempontokkal is (szakoktatók képzése, tanári minor szakos hallgatók) 4. Az előző két szempont miatt is célszerü lenne, ha a képzőintézmények határozhatnák meg a tartalmi arányokat. 5. A gyakorló iskolák szerepe az ötödik féléves összefüggő gyakorlatban és a mentorképzésben? 6. A blokk- vagy kísérőszeminárium ügyében a hozzászólók a folyamatosságot támogatták.

Brezsnyánszky László dékán (Nyíregyházi Föiskola) A képzés folyamatszervezése c. szekció vezetője beszámolt munkájuk következő három kiemelt területéröl: 1. A gyakorlat koordinálása 2. Értékelés (kik, kiket, hogyan) 3. Finanszírozás témájában nemcsak az merült fel, hogy miből, hanem a kik, kiket megosztás is, mely egyaránt kell, hogy érintse a felső- és a közoktatási forrásokat is. Tovább felvetödött a foglalkoztatási alap bevonása a 6 . félév kérdésének megoldásába.

A beszámolók összefoglalásaként Hunyady György megállapította, hogy a munkaanyaggal kapcsolatos „hangulat” alapvetően pozitív, koncepcióját helyesnek és konstruktívak ítélték a hozzászólók. A Javaslat szövege viszont még tömöríthető, átdolgozandó. A szabályozási és az ajánlás részeket egyértelműen kellene benne 
elválasztani. Az pedig egyértelmü, hogy jelenleg nincsen elegendő pénz a megvalósításhoz. Az anyagi háttér elteremtéséhez is szükséges a partnerség.

A munkaanyag és az előadók prezentációi elérhetők az OFI honlapján: http:// www.ofi.hu/rolunk/konferenciak/partnerek-tanarkepzesben 